\title{
Uşak Koşullarında Kızıltan-91 Buğday Çeşidi Üzerinde Farklı Azot Dozu ve Sıvı Gübre Uygulamalarının Verim ve Verim Unsurlarına Etkisi
}

\author{
Aliye ALTUNTAŞ1, İlknur AKGÜN² \\ 1Ulubey İlçe Gıda Tarım ve Hayvancılık Müdürlüğü, 64400, Uşak \\ ${ }^{2}$ Süleyman Demirel Üniversitesi, Ziraat Fakültesi, Tarla Bitkileri Bölümü, 32160, Isparta
}

(Alınış / Received: 23.03.2016, Kabul / Accepted: 02.06.2016, Online Yayınlanma / Published Online: 13.11.2016)

\begin{abstract}
Anahtar
Özet: $\mathrm{Bu}$ araştırma, farklı azot dozu (8 ve $14 \mathrm{~N} \mathrm{~kg} / \mathrm{da}$ ) ve sıvı gübre uygulamalarının (Amino Kelimeler Buğday,

Azot, Sivi gübre, Verim, Turbo, Biomax, Süper Tonik, Folvinex ) Kızıltan-91 makarnalık buğday çeşidi üzerinde verim ve verim unsurlarına etkisinin belirlemek amacıyla, 2013 yılında Uşak şartlarında yürütülmüştür. Araştırma, Bölünmüş Parseller Deneme planına uygun olarak 3 tekerrürlü kurulmuștur. Azot dozları ana parsellere, uygulamalar ise alt parsellere (Azotlu gübreleme $1.1 \backslash 2$ ekimle $+1 \backslash 2$ sapa kalkma başlangıcı(erken ilkbahar) 2. 1/3 ekimle $+1 / 3$ erken ilkbaharda $+1 / 3$ sapa kalkma, 3. 1/2 Kalite ekimle $+1 / 2$ erken ilkbahar +Amino turbo, 4. 1/2 ekimle $+1 / 2$ erken ilkbahar + Biomax, 5. 1/2 ekimle $+1 / 2$ erken ilkbahar + Süper tonik ve $6.1 / 2$ ekimle $+1 / 2$ erken ilkbahar + Folvinex yerleștirilmiștir. Ekimle birlikte bütün parsellere dekara $7 \mathrm{~kg} \mathrm{P}_{2} \mathrm{O}_{5}$ hesabiyla fosforlu gübre uygulanmıștır. Araştırma sonucuna göre, azot dozlarının bitki boyunu, metrekaredeki başak sayısını, başaktaki tane sayısını, başaktaki tane ağırlığını, tane verimini ve ham protein içeriğini istatistiksel olarak önemli seviyede arttırdığı, ancak hektolitre ve bin tane ağırlı̆ı ile camsılık özelliği üzerine önemli bir etkisinin olmadığı belirlenmiștir. Azotun farklı zamanlarda bölünerek ve sıvı gübre ilaveli uygulamalarında ise camsılık özelliği hariç, incelenen diğer tarımsal özelliklerde istatistiksel olarak önemli bir etkisinin bulunduğu belirlenmiştir. Kızıltan-91 çeşidinde en yüksek tane verimi $14 \mathrm{~kg}$ azot dozunda $1 / 2$ ekimle $+1 / 2$ erken ilkbahar + Folvinex uygulamasından elde edilmiștir. Ayrıca tane verimi ve kalite özelliği üzerine, azotun 3 farklı zamanda verilmesinin önemli bir etkisinin olmadığı, ancak Folvinex adı ile satılan sıvı gübrenin diğerlerine göre daha etkili olduğu belirlenmiştir.
\end{abstract}

\section{Influence of Different Nitrogen Dose and Liquid Fertilizer Applications on Yield and Yield Components of Kızıltan-91 Wheat Cultivar under Uşak Conditions}

Keywords

Wheat,

Nitrogen,

Liquid

fertilizer,

Yield,

Quality
Abstract: The research was carried out to determinate the effects of different nitrogen dose (8 and $14 \mathrm{~N} \mathrm{~kg} / \mathrm{da}$ ) and liquid fertilizer applications ((Amino Turbo, Biomax, SüperTonik, Folvinex) on yield and yield components of kızıltan-91 wheat cultivar under the ecological conditions of Uşak in 2013. The study was established on split-plot design with 3 replications. The nitrogen dose took place in the main plots whereas the applications were in the sub-plots (nitrogen fertilizer $1.1 \backslash 2$ at sowing $+1 \backslash 2$ initiation of stem elongation stage (early spring ) 2. $1 / 3$ at sowing $+1 / 3$ early spring $+1 / 3$ the stem elongation, $3.1 / 2$ at sowing $+1 / 2$ early spring + Amino turbo, 4. $1 / 2$ at sowing $+1 / 2$ early spring + Biomax, $5.1 / 2$ at sowing $+1 / 2$ early spring + Süper tonik and $6.1 / 2$ at sowing $+1 / 2$ early spring + Folvinex). According to the results, nitrogen doses increased significantly plant height, number of spike per square meter, the number of grain per spike, the weight of grain per spike grain yield and crude protein content but the effects of the nitrogen applications on test weight, thousand kernel weights and vitreousness were not significant. On the other hand, it was found that in the different time of nitrogen by dividing and added liquid fertilizer applications had significant effect on examined agronomic properties (except vitreousness ). In the research it was determined that the highest grain yield was obtained by applying $14 \mathrm{~kg} \mathrm{~N} / \mathrm{da}$ as $1 / 2$ at sowing $+1 / 2$ early spring + Folvinex. Also it was indicated that nitrogen given in three different times was not affected significantly on the yield and quality characteristics and the liquid fertilizer sold the name Folvinex was more effective than others. 


\section{Giriş}

Dünyada ekiliş ve üretimi en fazla ürün grubu tahıllar olup, insan beslenmesinin yanında hayvan beslenmesinde ve endüstride yaygin olarak kullanılmaktadır. Tahıllar arasında buğday, dünyada üretim bakımından üçüncü sırada yer almaktadır [1]. Türkiye'de buğday, 78.668 .874 da ekim alanı (\%67.5), 22.600 .000 ton üretimi, $287 \mathrm{~kg} / \mathrm{da}$ verimi ile ilk sırada yer almaktadır [2]. Ülkemizde kişi başına buğday tüketiminin $195 \mathrm{~kg}$ olduğu düşünülürse gelecekte de buğday üretimi ve tüketiminin stratejik önemini koruyacağı açıtır.

Geçit kuşağında yer alan Uşak, ortalama $600 \mathrm{~mm}$ yağışa sahiptir ve bu da bölgede buğday veriminin artırılmasını mümkün kılmaktadır. 2014 yılı verilerine göre Uşak ilinde yaklaşık olarak 747.994 dekar alanda ekim yapılmakta ve yaklaşık olarak 151.681 ton ürün alınmaktadır. Dekara verim ise 215 kg ile Türkiye ortalamasının altında yer almaktadır [2].

Buğdayda birim alandan elde edilecek verimi arttırmanın yollarından birisi de, bölgeye adapte olmuş çeşitlerin, optimum yetiştirilme teknikleri altında uygun gübreleme metotları ile mümkün olabilmektedir. Yöremizde de buğday yetiştiriciliğinde kültürel uygulamalar sırasında ortaya çıkan sıkıntıların başında uygun gübre çeșit ve miktarının kullanılmaması gelmektedir. Azot, üretimde normal bitki gelişimini sınırlayan en önemli besin elementidir. Araştırma sonuçlarına göre azotlu gübrelemenin verim artışında payı büyük olup bu oranın \% 50'nin üzerinde olduğu saptanmıștır [3]. Buğdayın optimum vejetatif ve generatif gelişmeyi gösterebilmesi için, azota olan ihtiyacının diğer besin maddelerine oranla daha yüksek olduğu belirtilmiștir [4].

Bu çalışmada, Uşak yöresinde yaygın olarak tarımı yapılan Kızıltan-91 makarnalık buğday çeşidinin verim ve verim özelliklerinin kültürel uygulamalarda yapılan değişikliklerle artırılması amaçlanmaktadır. TMO buğday alımında fiziksel değerlerin yanında, protein oranını da esas alan bir alım yapmaktadır. $\mathrm{Bu}$ durum çiftçileri farklı arayışlara, özellikle de gübre satıcılarının önerileri doğrultusunda fazla gübre kullanmaya yöneltmiştir. Ancak fazla gübre kullanımı maliyeti arttırdığı gibi sürdürülebilir tarım açısından çevreye de birçok olumsuz etkileri bulunmaktadır. $\mathrm{Bu}$ nedenle uygulanan gübrenin bitkilerin kullanabileceği dönemde verilmesi ve bu sistemin de uygulanabilir olması önemlidir. Bu araştırma ile Uşak şartlarına uygun gübreleme şeklinin belirlenmesi birim alandan en yüksek verimin alınması ve üreticilere benimsetilmesi amaçlanmıştır.

\section{Materyal ve Metot}

Tarla denemesi: Uşak ili Ulubey ilçesi Omurca beldesi kuru koşullarında 2012-2013 yıllarında yürütülmüştür. Çalışmada materyal olarak Uşak ve çevresinde yaygın olarak yetiştirilen Kızıltan-91 makarnalık buğday çeşidi kullanılmıştır Araştırma, Tesadüf Bloklarında Bölünmüş Parseller Deneme planına uygun olarak 3 tekerrürlü kurulmuștur. Ana parseller azot dozları $(8,14 \mathrm{~N} \mathrm{~kg} / \mathrm{da})$, alt parsellere ise uygulamalar yerleştirilmiştir (Tablo 1). Ekimle birlikte bütün parsellere dekara $7 \mathrm{~kg} \mathrm{P}_{2} \mathrm{O}_{5}$ hesabiyla fosforlu gübre uygulanmıştır. Yabancı ot mücadelesinde $200 \mathrm{cc} /$ da aktif madde hesabıyla 2.4D terkipli herbisit kullanılmıştır. Parsel boyutları $5 \mathrm{~m}$ x $1.2 \mathrm{~m}=6 \mathrm{~m}^{2}$ olmuştur. Her parselde $20 \mathrm{~cm}$ sira aralığın da 6 sıra yer alacak ve $\mathrm{m}^{2}$ ye 500 tohum düşecek şekilde 4 Kasım tarihinde ekim yapılmıştır. Deneme 36 parselden oluşmuştur (2 azot dozu x 6 uygulama $\times 3$ tekerrür $=36$ ). Kullanılan sivı gübrelerin içerikleri aşağıda belirtilmiştir.

1. Amino turbo : Toplam organik madde : $\% 75$ ,Toplam Azot : \%10 ,Organik Azot : \%2, Serbest Amino asit : \%30, Humik + Fulvik asit :\%1,Azami nem miktarı : \%20, Ph aralığı : 3-5, Formülasyon suda çözünen toz(sp)

2. Biomax: Bakır :(\%1), demir (\%2), Çinko (\%2) ve diğer mikro besin elementleri

3. Süper Tonik: $2 \mathrm{~g} / \mathrm{l}$ sodium orthonitrophenolate, $3 \mathrm{~g} / \mathrm{l}$ sodium para nitrophenolate, $1 \mathrm{~g} / \mathrm{l}$ sodium pentanitroguaiacolate

4. Folvinex : Ec Fertilizer Aminoasit katkılı sivı organik gübre, Organik madde : $\% 30$, Toplam Azot : \%3, organik Azot : \%2, Toplam serbest aminoasit : \%7, Suda çözünür Potasyum Oksit :\%3

Araştırmada bitki boyu (cm), metrekarede başak sayısı (adet), başaktaki tane sayısı (adet), başakta tane ağırlığı (g), dekara tane verimi $(\mathrm{kg} / \mathrm{da})$, bin tane ağırlığı (g), hektolitre ağırlığı, camsılık özelliği ve protein oranı incelenmiştir [5].

Tablo 1. Azotun ve sıvı gübrelerin uygulama șekilleri

\begin{tabular}{ll}
\hline Uygulamalar \\
\hline 1. & $\begin{array}{l}1 \backslash 2 \text { ekimle beraber ve } 1 \backslash 2 \text { sapa kalkma başlangıcı (erken ilkbahar) azotlu gübre olarak } \\
\text { verilmesi (genel üretici uygulaması kontrol olarak değerlendirilecektir.) }\end{array}$ \\
\hline 2. & $\begin{array}{l}1 / 3 \text { ekimle birlikte }+1 / 3 \text { erken ilkbaharda }+1 / 3 \text { sapa kalkma (Feekes skalasına göre } 6 . \text { ve } 7 . \\
\text { dönem) }\end{array}$ \\
\hline 3. & $1 / 2$ ekimle $+1 / 2$ erken ilkbahar + Amino turbo (herbisitle birlikte uygulama) \\
\hline 4. & $1 / 2$ ekimle $+1 / 2$ erken ilkbahar + Biomax (herbisitle birlikte uygulama) \\
\hline 5. & $1 / 2$ i ekimle $+1 / 2$ erken ilkbahar + Süper Tonik (herbisitle birlikte uygulama) \\
\hline 6. & $1 / 2$ ekimle $+1 / 2$ erken ilkbahar + Folvinex (herbisitle birlikte uygulama) \\
\hline
\end{tabular}


Tablo 2. Deneme yılına ve uzun yıllara ait iklim verileri*

\begin{tabular}{|c|c|c|c|c|c|c|c|c|c|c|c|c|c|}
\hline & Yillar & Eylül & Ekim & $\begin{array}{l}\text { Kası } \\
\mathrm{m}\end{array}$ & $\begin{array}{l}\text { Aralı } \\
\mathrm{k}\end{array}$ & Ocak & Şubat & Mart & Nisan & Mayıs & Haz. & Tem. & $\begin{array}{l}\text { Ort./ } \\
\text { Top. }\end{array}$ \\
\hline \multirow{4}{*}{$\begin{array}{l}\text { Aylık } \\
\text { Sicak. } \\
\left({ }^{\circ} \mathrm{C}\right)\end{array}$} & 2012 & $23.1^{*}$ & 16.6 & 10.9 & 5.3 & 3.1 & 5.7 & 8.4 & 13.2 & 19.6 & 23.2 & 25.4 & 14.1 \\
\hline & - & & & & & & & & & & & & \\
\hline & 2013 & & & & & & & & & & & & \\
\hline & $\begin{array}{l}\text { Uzun } \\
\text { Yillar }\end{array}$ & 19.0 & 13.3 & 7.9 & 4.2 & 2.4 & 3.1 & 6.2 & 10.8 & 15.7 & 20.2 & 23.6 & 11.5 \\
\hline \multirow{4}{*}{$\begin{array}{l}\text { Aylık } \\
\text { Yağış } \\
(\mathrm{mm})\end{array}$} & 2012 & 13.3 & 76.0 & 29.9 & 169.5 & 99.7 & 92.1 & 50.7 & 48.7 & 38.6 & 10.1 & 55.7 & 684.1 \\
\hline & - & & & & & & & & & & & & \\
\hline & 2013 & & & & & & & & & & & & \\
\hline & $\begin{array}{l}\text { Uzun } \\
\text { Yillar }\end{array}$ & 17.0 & 40.9 & 59.3 & 79.4 & 73.2 & 65.4 & 56.4 & 53.0 & 48.0 & 27.0 & 16.5 & 536.4 \\
\hline
\end{tabular}

*Uşak Meteoroloji İstasyonu verileri

Denemenin kurulduğu alanın toprakları killi-tınlı bir yapıya sahiptir. Toprak reaksiyonu nötr ve kireçli yapıdadır. Tuzluluk problemi bulunmamakta olup, toplam azot $(\mathrm{N})$ bakımında fakir ve organik madde oranı düşüktür. Faydalı fosfor bakımından orta derecede olup, faydalı potasyum açısından ise yeterli düzeydedir.

Deneme yılındaki ayların ortalama sıcaklık değeri $\left(14.1^{\circ} \mathrm{C}\right)$, uzun yillar ortalamasindan $\left(11.5^{\circ} \mathrm{C}\right)$ daha fazla bulunmuștur. Ortalama minimum ve maksimum sıcaklık değerleri; deneme yılında $7.6^{\circ} \mathrm{C}$ ve $18.9^{\circ} \mathrm{C}$ iken, uzun yıllar ortalamasinda $6.1{ }^{\circ} \mathrm{C}$ ve $17.4{ }^{\circ} \mathrm{C}$ dir. Ortalama nispi nem deneme yılında \%59 iken, uzun yıllar ortalaması \% 64.4 tür. Toplam yağış miktarı deneme yılında $684.1 \mathrm{~mm}$, uzun yıllar toplam yağış miktarı ise $536.4 \mathrm{~mm}$ 'dir. (Tablo 2).

\section{Bulgular ve Tartışma}

\subsection{Bitki boyu}

Kızıltan-91 buğday çeşidinin bitki boyuna, farklı azot dozlarının ve sıvı gübre uygulamasının etkisi çok önemli $(\mathrm{p}<0.01)$ bulunmuștur. Ortalama bitki boyu, 8 $\mathrm{kg} / \mathrm{da} \mathrm{N}$ dozunda $77.2 \mathrm{~cm}$ iken, $14 \mathrm{~kg} / \mathrm{da} \mathrm{N}$ uygulamasında $79.5 \mathrm{~cm}$ olarak elde edilmiş ve istatistiksel olarak farklı gruplarda yer almıştır (Tablo 3). [6] tarafından, yaplan çalışmada bitki boyunun, azot dozuna bağlı olarak artış gösterdiği belirlenmiştir.

Azot verilme zamanı ve sıvı gübre uygulamalarında ise en yüksek bitki boyu 2 [79.9 cm (1/3 ekim+1/3 erken ilkbahar + $1 / 3$ sapa kalkma)] numaralı uygulamadan elde edilmiș ve bu değer ile 5 numaralı uygulama hariç diğerleri arasındaki farklılık önemli olmamıștır (Tablo 3). Sıvı gübre uygulamalarının bitki boyunu önemli seviyede arttırıcı yönde olumlu bir etkisi olmadığı gibi Süper tonik uygulamasının azaltıcı bir etkisi belirlenmiştir. 2 numaralı uygulamada görüldüğü gibi azot bölünerek verildiğinde bitki boyu artmıştır. Ancak kontrol olarak ele aldığımız genel uygulama olan 2 numaralı uygulama ile önemli bir farklılık meydana gelmemiştir. [7] tarafından yapılan çalışmada ise, en yüksek bitki boyu azotlu gübrenin tamamının ekimle verildiği (18 kg/da ekimle birlikte) uygulamada elde edilmiştir.

\subsection{Metrekaredeki başak sayısı (adet)}

Ortalama metrekaredeki başak sayısı, $8 \mathrm{~kg} / \mathrm{da} \mathrm{N}$ dozunda 378.56 adet iken, $14 \mathrm{~kg} / \mathrm{da} \quad \mathrm{N}$ uygulamasında 400.72 adet olarak elde edilmiş ve istatistiksel olarak farklı gruplarda yer almıştır (Tablo 4). Kızıltan -91 buğday çeşidinde farklı azot dozları ve sıvı gübre uygulamasında en fazla $\mathrm{m}^{2}$ 'deki başak sayısı (430.67 adet) $14 \mathrm{~kg} / \mathrm{da}$ azot dozunda 1 numaralı uygulama olan azotun $1 \backslash 2$ ekimle beraber, $1 \backslash 2$ 'si erken ilkbaharda üst gübre olarak verilmesinden elde edilmiştir. Azot dozu azaltıldığında ise ( $8 \mathrm{~kg} / \mathrm{da}), 6$ numara ile verilen $(1 \backslash 2$ ekimle beraber, $1 \backslash 2$ erken ilkbaharda+ folvinex) uygulamada belirlenmiștir. Ancak bu uygulama ile 1 numaralı ( $1 \backslash 2$ ekimle + $1 \backslash 2$ sapa kalkma bașlangıcı) uygulama arasında istatistiki olarak fark bulunmamıștır (Tablo 4).

Özellikle hem $8 \mathrm{~kg} / \mathrm{da}$ hem de $14 \mathrm{~kg} / \mathrm{da}$ azot uygulamasında ekimle birlikte verilen azotun fazla olması, yani atılacak miktarın yarısının ekimle verilmesi $\mathrm{m}^{2}$ deki başak sayısını önemli seviyede arttırmıştır. $\mathrm{Bu}$ durum azotun birim alana ekilen tohumun çimlenmesine olumlu etkisi ya da kardeşlenme kapasitesini önemli seviyede arttırması ile açıklanabilir. Coşkun[8] , makarnalık buğdayda yaptığı çalışmada, azot uygulamasının tane verimi ve verim unsurları üzerine olumlu etki yaptığını ve $\mathrm{m}^{2}$ 'de en fazla bașak sayısının azotun tamamının ekimle birlikte (448.2 adet) ve $1 / 2$ ekim ile+1/2 kardeșlenme döneminde verilmesiyle (432.33 adet) elde edildiğini bildirmiştir. Diğer taraftan, verilen azotun az olması durumunda daha sonra verilecek bazı yaprak gübreleri gelișen kardeșlerin başak bağlamasına katkıda bulunabilmiștir. Nitekim herbisit uygulaması ile birlikte verilen Folvinex adı ile piyasada satılan sıvı gübrenin azot dozunun düșük (8 $\mathrm{kg} / \mathrm{da}$ ) olduğu parsellerde gelișen kardeșlerin başak bağlamasını sağlamış ve en yüksek değer (386.7 adet) bu uygulamada elde edilmiştir. 


\subsection{Başaktaki tane sayısı (adet)}

Ortalama başaktaki tane sayısı, $8 \mathrm{~kg} / \mathrm{da} \mathrm{N}$ dozunda 30.50 adet iken, $14 \mathrm{~kg} / \mathrm{da} \mathrm{N}$ uygulamasında 31.62 adet olarak elde edilmiş ve bu farklılık istatistiksel olarak çok önemli bulunmuştur $(\mathrm{p}<0.01)$. Azot dozları (8 kg/da ve $14 \mathrm{~kg} / \mathrm{da}$ ) ortalamalarına baktığımızda ise, azot verilme zamanı ve sıvı gübre uygulamalarında en yüksek başakta tane sayısı 6 numaralı uygulamada $(1 / 2$ ekim $+1 / 2$ erken ilkbahar +Folvinex) belirlenmiş (32.53 adet) ve bu değer ile diğerleri arasındaki farklılık önemli bulunmuştur. Bu değeri 4. Uygulama (1/2ekim+1/2erken ilkbahar +Biomax) takip etmiştir. Başakta tane sayısı yönünden diğer uygulamalar arasında istatiksel olarak fark bulunmamıştır. Azota ilaveten herbisit uygulaması ile birlikte verilen Folvinex, kardeşlerin başak bağlamasını sağladığı gibi, başaktaki tane sayısını da artırmıștır (Tablo 5). Buğdayda her başaktaki tane sayısı, tane veriminin belirlenmesinde önemli bir kriterdir. Azotlu gübrelemenin her başaktaki başakçık sayısını dolayısı ile tane sayısını arttırdığı farklı çalışmalarda belirlenmiştir [9] ; [10].

Tablo 3. Farklı azot dozu ve sıvı gübre kullanımlarında bitki boyuna $(\mathrm{cm})$ ilişkin ortalamalar

\begin{tabular}{|c|c|c|c|c|}
\hline \multirow[b]{2}{*}{ No } & \multirow[b]{2}{*}{ Azot ve Sıvı Gübre Uygulamaları } & \multicolumn{2}{|c|}{ Azot Dozları (kg/da) } & \multirow[b]{2}{*}{ Ortalama } \\
\hline & & 8 & 14 & \\
\hline 1 & 1/2 ekim+1/2 sapa kalkma bașlangıcı & 77.1 & 80.7 & $78.9 \mathrm{ab}^{*}$ \\
\hline 2 & $\begin{array}{l}1 / 3 \text { ekim }+1 / 3 \text { erken ilkbahar }+1 / 3 \\
\text { sapa kalkma }\end{array}$ & 78.8 & 80.9 & $79.9 \mathrm{a}$ \\
\hline 3 & $\begin{array}{l}1 / 2 \text { ekim }+1 / 2 \text { erken ilkbahar }+ \text { amino } \\
\text { turbo }\end{array}$ & 77.3 & 79.2 & $78.2 \mathrm{ab}$ \\
\hline 4 & $1 / 2$ ekim $+1 / 2$ erken ilkbahar + biomax & 77.5 & 80.9 & $79.2 \mathrm{ab}$ \\
\hline 5 & $\begin{array}{l}1 / 2 \text { ekim }+1 / 2 \text { erken ilkbahar +süper } \\
\text { tonik }\end{array}$ & 75.7 & 77.6 & $76.6 \mathrm{~b}$ \\
\hline 6 & $1 / 2$ ekim $+1 / 2$ erken ilkbahar + folvinex & 76.7 & 77.4 & $77.01 \mathrm{ab}$ \\
\hline & Ortalama & $77.2 \mathrm{~B}$ & $79.5 \mathrm{~A}$ & \\
\hline
\end{tabular}

F değerleri : Azot Dozu (A) : $1065.484^{* *}$; Uygulama(B): $6.424^{* *}$ A X B: 1.228

$\mathrm{CV}(\mathrm{a})=\% 0,27, \mathrm{CV}(\mathrm{b})=\% 1,57$

${ }^{*}$ Aynı harfle gösterilen değerler arasında istatistiksel olarak fark yoktur. ${ }^{* *}: \mathrm{P} \leq 0.01$ düzeyinde

Tablo 4. Farklı azot dozu ve sıvı gübre kullanımlarında metrekaredeki başak sayısına olan etkisi

\begin{tabular}{|c|c|c|c|c|}
\hline \multirow[b]{2}{*}{ No } & \multirow[b]{2}{*}{ Azot ve Sıvı Gübre Uygulamaları } & \multicolumn{2}{|c|}{ Azot Dozları (kg/da) } & \multirow[b]{2}{*}{ Ortalama } \\
\hline & & 8 & 14 & \\
\hline 1 & 1/2 ekim+1/2 sapa kalkma bașlangıcı & $379.67 \mathrm{ab}^{*}$ & $430.67 a^{*}$ & 405.17 \\
\hline 2 & $\begin{array}{l}1 / 3 \text { ekim }+1 / 3 \text { erken ilkbahar }+1 / 3 \text { sapa } \\
\text { kalkma }\end{array}$ & $374.67 \mathrm{~b}$ & 392.67 c & 383.66 \\
\hline 3 & $\begin{array}{l}\frac{1}{2} \text { ekim }+1 / 2 \text { erken ilkbahar }+ \text { amino } \\
\text { turbo }\end{array}$ & $376.67 \mathrm{~b}$ & $396.67 \mathrm{bc}$ & 386.66 \\
\hline 4 & $1 / 2$ ekim $+1 / 2$ erken ilkbahar + biomax & $376.00 \mathrm{~b}$ & $390.67 \mathrm{c}$ & 383.33 \\
\hline 5 & $1 / 2$ ekim+1/2erken ilkbahar + süper tonik & $377.67 \mathrm{~b}$ & 393.33 c & 385.50 \\
\hline \multirow[t]{2}{*}{6} & $1 / 2$ ekim $+1 / 2$ erken ilkbahar + folvinex & $386.67 \mathrm{a}$ & $400.33 \mathrm{~b}$ & 393.50 \\
\hline & Ortalama & $378.56 \mathrm{~B}$ & $400.72 \mathrm{~A}$ & \\
\hline
\end{tabular}

F değerleri : Azot Dozu (A) : $361^{* *}$; Uygulama(B): 29.534** A X B: $21.157^{* *}$

$\mathrm{CV}(\mathrm{a})=\% 1,90, \mathrm{CV}(\mathrm{b})=\% 1,98$

${ }^{*}$ Aynı harfle gösterilen değerler arasında istatistiksel olarak fark yoktur. ${ }^{* *}: \mathrm{P} \leq 0.01$ düzeyinde önemli

Tablo 5. Farklı azot dozu ve sıvı gübre kullanımlarının başaktaki tane sayısına olan etkisi

\begin{tabular}{|c|c|c|c|c|}
\hline \multirow[b]{2}{*}{ No } & \multirow[b]{2}{*}{ Azot ve Sıvı Gübre Uygulamaları } & \multicolumn{2}{|c|}{ Azot Dozları (kg/da) } & \multirow[b]{2}{*}{ Ortalama } \\
\hline & & 8 & 14 & \\
\hline 1 & 1/2 ekim+1/2 sapa kalkma başlangıcl & 29.47 & 30.80 & $30.13 \mathrm{c}^{*}$ \\
\hline 2 & $1 / 3$ ekim $+1 / 3$ erken ilkbahar $+1 / 3$ sapa kalkma & 30.10 & 30.90 & $30.50 \mathrm{c}$ \\
\hline 3 & $1 / 2$ ekim $+1 / 2$ erken ilkbahar + amino turbo & 30.37 & 31.23 & $30.80 \mathrm{c}$ \\
\hline 4 & $1 / 2$ ekim $+1 / 2$ erken ilkbahar + biomax & 31.20 & 32.03 & $31.61 \mathrm{~b}$ \\
\hline 5 & $1 / 2$ ekim+1/2erken ilkbahar +süper tonik & 30.27 & 31.33 & $30.80 \mathrm{c}$ \\
\hline 6 & $1 / 2$ ekim $+1 / 2$ erken ilkbahar + folvinex & 31.60 & 33.47 & $32.53 \mathrm{a}$ \\
\hline & Ortalama & $30.50 \mathrm{~B}$ & $31.62 \mathrm{~A}$ & \\
\hline
\end{tabular}

F değerleri : Azot Dozu (A) : 195.303**; Uygulama(B) : 27.897**, A X B : 1.573

$\mathrm{CV}(\mathrm{a})=\% 0,78, \mathrm{CV}(\mathrm{b})=\% 1,3$

${ }^{*}$ Aynı harfle gösterilen değerler arasında istatistiksel olarak fark yoktur. ${ }^{* *}: \mathrm{P} \leq 0.01$ düzeyinde önemli 


\subsection{Başaktaki tane ağırlığı (g)}

Kızıltan -91 buğday çeşidinde başakta tane ağırlığına, farklı azot dozlarının $(\mathrm{p}<0.05)$, uygulamaların $(p<0.01) v e$ azot dozu $x$ farklı uygulama interaksiyonunun $(p<0.01)$ etkisi değișen seviyelerde önemli bulunmuştur (Tablo 6). Ortalama başaktaki tane ağırlığı $8 \mathrm{~kg} / \mathrm{da} \mathrm{N}$ uygulamasında $1.19 \mathrm{~g}$ iken, 14 $\mathrm{kg} /$ da N uygulamasında $1.24 \mathrm{~g}$ olarak belirlenmiștir. Araştırmada azot verilme zamanı ve sıvı gübre uygulamalarında en yüksek başakta tane ağırlığı, her iki azot dozunda 6 numaralı uygulamada $(1 / 2$ ekim $+1 / 2$ erken ilkbahar +Folvinex) saptanmıștır.

Azotu üçe bölerek verilmesi, yani 2. uygulama ile başakta tane ağırlığı, azotun azaltıldığ $(8 \mathrm{~kg} / \mathrm{da})$ durumda ve $14 \mathrm{~kg}$ uygulamasinda elde edilen sonuçlar benzer olmuştur. Alcoz et al.,[11] tarafından yapılan çalışmada buğdaya 7.5 ve $15 \mathrm{~kg} / \mathrm{da}$ saf azot dozları uygulanmış, azotun tek seferde uygulanması yerine bölünerek uygulanmasının, tane verimini arttırdığını, bunun da birim alandaki başaktaki tane ağırlığının artmasından kaynaklandığını vurgulamışlardır.

\subsection{Dekara tane verimi $(\mathrm{kg})$}

Kızıltan-91 makarnalık buğday çeşidinde dekara tane verimi üzerine, farklı azot dozları ve uygulamaların etkisi çok önemli $(\mathrm{p}<0.01)$ bulunmuştur (Tablo 7). Nitekim ortalama tane verimi $8 \mathrm{~kg} / \mathrm{da} \quad \mathrm{N}$ uygulamasinda $447.33 \mathrm{~kg}$ iken, $14 \mathrm{~kg} / \mathrm{da} \quad \mathrm{N}$ uygulamasında $495.27 \mathrm{~kg}$ olarak elde edilmiștir. Azotun farklı şekillerde uygulaması ya da sıvı gübre ilavesi durumunda ise, dekara en yüksek tane verimi 6 numaralı uygulamadan $(1 / 2$ ekim le $+1 / 2$ erken ilkbahar + Folvinex) belirlenmiştir. Bu çalışmada her iki azot dozunda (8 $\mathrm{kg} / \mathrm{da}$ ve $14 \mathrm{~kg} / \mathrm{da}$ ) azotun genel uygulama olan 2'ye bölünerek yani atılacak miktarın yarısının ekimle verilmesi dekara tane verimini önemli seviyede arttırmıștır (Tablo 7). Bu durum azotun birim alana ekilen tohumun çimlenmesine olumlu etkisi ya da kardeşlenme kapasitesini önemli seviyede arttırması ile açıklanabilir. Diğer taraftan verilen azotun az olması durumunda daha sonra verilecek bazı yaprak gübreleri gelişen kardeşlerin başak bağlamasına katkıda bulunabilmektedir. Nitekim herbisit uygulaması ile birlikte verilen Folvinex, azot dozu azaltıldığında $(8 \mathrm{~kg} / \mathrm{da}$ olduğunda) gelișen kardeșlerin başak bağlamasını sağlamış ve en yüksek değer $(496.33 \mathrm{~kg})$ bu uygulamada elde edilmiştir. Ekmeklik buğday üzerinde yapılan bir çalışmada azot uygulama zamanı yönünden, ekim zamanı ve sapa kalkma başlangıcının tane verimi yönünden daha kritik öneme sahip olduğu bildirilmiştir [12].

\subsection{Bin tane ağırlığı (g)}

Bin tane ağırlığına, farklı azot dozlarının etkisi önemsiz iken, sıvı gübre uygulamasının etkisi ve azot dozu x sıvı gübre uygulaması interaksiyonu çok önemli $(\mathrm{p}<0.01)$ bulunmuștur. Ortalama bin tane ağırlığı $8 \mathrm{~kg} / \mathrm{da}$ uygulamasında $38.89 \mathrm{~g}$ iken, 14 $\mathrm{kg} / \mathrm{da} 39.89 \mathrm{~g}$ olarak belirlenmiş, ancak bu farklılık önemli olmamıştır (Tablo 8). Araştırmada özellikle azotun düşük seviyede verilmesi durumunda, tüm sıvı gübrelerin ve azotun üçe bölünerek verilmesinin olumlu etkisinin daha fazla olduğu belirlenmiștir.

Farklı araștırmalarda azotun bölünerek verilmesinin bin tane ağırlığı üzerine olumlu etkisinin olduğu bildirilmiştir [13; 14; 15; 16]. Bu araştırmada ise azotun farklı zamanlarda verildiği uygulamalar arasında (2 ve 1 numaralı uygulama) önemli bir farklılık bulunmamıştır. Bu durum azotun verilme zamanının farklı olması ya da çevre şartlarından kaynaklanabilir. Sonuç olarak piyasada Amino turbo ve Folvinex adı ile satılan sıvı gübrelerin 1000 tane ağırlığına önemli katkı sağladığı belirlenmiştir.

Tablo 6. Farklı azot dozu ve sıvı gübre kullanımlarının bașaktaki tane ağırlığına olan etkisi

\begin{tabular}{|c|c|c|c|c|}
\hline \multirow[b]{2}{*}{ No } & \multirow[b]{2}{*}{ Azot ve Sıvı Gübre Uygulamaları } & \multicolumn{2}{|c|}{ Azot Dozları (kg/da) } & \multirow[b]{2}{*}{ Ortalama } \\
\hline & & 8 & 14 & \\
\hline 1 & 1/2 ekim+1/2 sapa kalkma başlangıcı & $1.04 \mathrm{~d}^{1}$ & $1.19 \mathrm{c}^{*}$ & 1.12 \\
\hline 2 & $\begin{array}{l}1 / 3 \text { ekim }+1 / 3 \text { erken ilkbahar }+1 / 3 \text { sapa } \\
\text { kalkma }\end{array}$ & $1.17 \mathrm{c}$ & $1.20 \mathrm{c}$ & 1.19 \\
\hline 3 & $\begin{array}{l}1 / 2 \text { ekim }+1 / 2 \text { erken ilkbahar }+ \text { amino } \\
\text { turbo }\end{array}$ & $1.18 \mathrm{c}$ & $1.27 \mathrm{ab}$ & 1.23 \\
\hline 4 & $1 / 2$ ekim $+1 / 2$ erken ilkbahar + biomax & $1.23 \mathrm{~b}$ & $1.23 \mathrm{bc}$ & 1.23 \\
\hline 5 & $1 / 2$ ekim+1/2erken ilkbahar +süper tonik & $1.23 \mathrm{~b}$ & $1.24 \mathrm{bc}$ & 1.23 \\
\hline 6 & $1 / 2$ ekim $+1 / 2$ erken ilkbahar + folvinex & $1.28 \mathrm{a}$ & $1.30 \mathrm{a}$ & 1.29 \\
\hline
\end{tabular}

F değerleri : Azot Dozu (A) : 19.216*; Uygulama(B) : 32.918**, A X B : 7.745**

$\mathrm{CV}(\mathrm{a})=\% 2,75, \mathrm{CV}(\mathrm{b})=\% 2,04$

${ }^{1}$ Aynı harfle gösterilen değerler arasında istatistiksel olarak fark yoktur.

*:P $\leq 0.05 ;{ }^{* *}: \mathrm{P} \leq 0.01$ düzeyinde önemli 
Tablo 7. Farklı azot dozu ve sıvı gübre kullanımlarının dekara tane verimi özelliğine olan etkisi

\begin{tabular}{|c|c|c|c|c|}
\hline \multirow[b]{2}{*}{ No } & \multirow[b]{2}{*}{ Azot ve Sıvı Gübre Uygulamaları } & \multicolumn{2}{|c|}{ Azot Dozları (kg/da) } & \multirow[b]{2}{*}{ Ortalama } \\
\hline & & 8 & 14 & \\
\hline 1 & 1/2 ekim+1/2 sapa kalkma başlangıcı & $396.00 \mathrm{~d}^{*}$ & $511.00 \mathrm{ab}$ & 453.50 \\
\hline 2 & $\begin{array}{l}1 / 3 \text { ekim }+1 / 3 \text { erken ilkbahar }+1 / 3 \text { sapa } \\
\text { kalkma }\end{array}$ & $435.33 \mathrm{c}$ & $470.33 \mathrm{~d}$ & 452.83 \\
\hline 3 & $\begin{array}{l}1 / 2 \text { ekim }+1 / 2 \text { erken ilkbahar }+ \text { amino } \\
\text { turbo }\end{array}$ & $438.33 \mathrm{c}$ & $500.67 \mathrm{bc}$ & 469.50 \\
\hline 4 & $1 / 2$ ekim $+1 / 2$ erken ilkbahar + biomax & $457.00 \mathrm{~b}$ & $481.33 \mathrm{~d}$ & 469.17 \\
\hline 5 & $1 / 2$ ekim+1/2erken ilkbahar +süper tonik & $461.00 \mathrm{~b}$ & $486.00 \mathrm{~cd}$ & 473.50 \\
\hline 6 & $1 / 2$ ekim $+1 / 2$ erken ilkbahar + folvinex & $496.33 \mathrm{a}$ & $522.33 \mathrm{a}$ & 509.33 \\
\hline & Ortalama & $447.33 \mathrm{~B}$ & $495.27 \mathrm{~A}$ & \\
\hline
\end{tabular}

F değerleri : Azot Dozu (A) : 416.305**; Uygulama(B) : 24.550**, A X B : 18.661** $\mathrm{CV}(\mathrm{a})=\% \% 1,5, \mathrm{CV}(\mathrm{b})=\% 2,16$

*Aynı harfle gösterilen değerler arasında istatistiksel olarak fark yoktur. **:P $\leq 0.01$ düzeyinde önemli

Tablo 8. Farklı azot dozu ve sıvı gübre kullanımlarının bin tane ağırlığına(g) olan etkisi

\begin{tabular}{|c|c|c|c|c|}
\hline \multirow[b]{2}{*}{ No } & \multirow[b]{2}{*}{ Azot ve Sıvı Gübre Uygulamaları } & \multicolumn{2}{|c|}{ Azot Dozları (kg/da) } & \multirow[b]{2}{*}{ Ortalama } \\
\hline & & 8 & 14 & \\
\hline 1 & 1/2 ekim+1/2 sapa kalkma başlangıcı & $37.00 \mathrm{~b}^{*}$ & $38.67 b^{*}$ & 37.83 \\
\hline 2 & $\begin{array}{l}1 / 3 \text { ekim }+1 / 3 \text { erken ilkbahar }+1 / 3 \text { sapa } \\
\text { kalkma }\end{array}$ & $39.17 \mathrm{a}$ & $39.33 \mathrm{~b}$ & 39.25 \\
\hline 3 & $\begin{array}{l}1 / 2 \text { ekim }+1 / 2 \text { erken ilkbahar }+ \text { amino } \\
\text { turbo }\end{array}$ & $39.33 \mathrm{a}$ & $41.00 \mathrm{a}$ & 40.17 \\
\hline 4 & $1 / 2$ ekim $+1 / 2$ erken ilkbahar + biomax & $37.83 \mathrm{~b}$ & $39.17 \mathrm{~b}$ & 38.50 \\
\hline 5 & $1 / 2$ ekim+1/2erken ilkbahar +süper tonik & $40.17 \mathrm{a}$ & $39.50 \mathrm{~b}$ & 39.83 \\
\hline \multirow[t]{2}{*}{6} & $1 / 2$ ekim $+1 / 2$ erken ilkbahar + folvinex & $39.83 \mathrm{a}$ & $41.67 \mathrm{a}$ & 40.75 \\
\hline & Ortalama & 38.89 & 39.89 & \\
\hline
\end{tabular}

F değerleri : Azot Dozu (A) : 4.747 ns ; Uygulama(B) : 23.757**, A X B : 5.215**

$\mathrm{CV}(\mathrm{a})=\% 3,5, \mathrm{CV}(\mathrm{b})=\% 1,38$

*Aynı harfle gösterilen değerler arasında istatistiksel olarak fark yoktur.

**:P $\leq 0.01$ düzeyinde önemli, ns: önemli değil

Tablo 9. Farklı azot dozu ve sıvı gübre kullanımlarının hektolitre ağırlığına olan etkisi

\begin{tabular}{|c|c|c|c|c|}
\hline \multirow[b]{2}{*}{ No } & \multirow[b]{2}{*}{ Azot ve Sıvı Gübre Uygulamaları } & \multicolumn{2}{|c|}{ Azot Dozları (kg/da) } & \multirow[b]{2}{*}{ Ortalama } \\
\hline & & 8 & 14 & \\
\hline 1 & 1/2 ekim+1/2 sapa kalkma başlangıcı & 78.09 & 79.24 & $78.67 b^{*}$ \\
\hline 2 & $\begin{array}{l}1 / 3 \text { ekim }+1 / 3 \text { erken ilkbahar }+1 / 3 \text { sapa } \\
\text { kalkma }\end{array}$ & 78.62 & 79.49 & $79.06 \mathrm{ab}$ \\
\hline 3 & $\begin{array}{l}1 / 2 \text { ekim }+1 / 2 \text { erken ilkbahar }+ \text { amino } \\
\text { turbo }\end{array}$ & 78.54 & 79.09 & $78.82 \mathrm{ab}$ \\
\hline 4 & $1 / 2$ ekim $+1 / 2$ erken ilkbahar + biomax & 78.72 & 78.44 & $78.58 \mathrm{~b}$ \\
\hline 5 & $1 / 2$ ekim+1/2erken ilkbahar +süper tonik & 78.12 & 78.65 & $78.39 \mathrm{~b}$ \\
\hline \multirow[t]{2}{*}{6} & $1 / 2$ ekim $+1 / 2$ erken ilkbahar + folvinex & 78.98 & 80.09 & $79.54 \mathrm{a}$ \\
\hline & Ortalama & 78.51 & 79.16 & \\
\hline
\end{tabular}

F değerleri : Azot Dozu (A) :5.812 ns ; Uygulama(B) : 4.841**, A X B : 2.0

$\mathrm{CV}(\mathrm{a})=\% 1,03, \mathrm{CV}(\mathrm{b})=\% 58$ 


\subsection{Hektolitre ağırlığı (kg)}

Ortalama hektolitre ağırlığı $8 \mathrm{~kg} / \mathrm{da}$ azot dozunda $78.51 \mathrm{~kg}$ iken, $14 \mathrm{~kg} / \mathrm{da}$ azot uygulamasında $79.16 \mathrm{~kg}$ olarak elde edilmiştir. Bu değerler arasındaki fark istatistiksel olarak önemli bulunmamıştır. Azotun farklı şekillerde uygulaması ya da sıvı gübre ilavesi durumunda ise istatistiksel olarak önemli farklllıklar belirlenmiștir (Tablo 9). Nitekim en fazla hektolitre ağılığı 6 numaralı uygulamadan $(1 / 2$ ekim ile $+1 / 2$ erken ilkbahar + Folvinex) elde edilmiştir. Azotun üçe bölünerek uygulanması ya da genel uygulama olan azotun 2 seferde verilmesi hektolitre ağırlığını önemli seviyede arttırmamıştır. [17], tarafından yapılan araștırmada azot dozu arttıkça $(0,34,67$ ve 101 $\mathrm{kg} / \mathrm{ha}$ ) hektolitre ağırlı̆̆ında artış elde edilmiştir. Bizim araştırmamızda elde ettiğimiz bulgulara benzer olarak; farklı araştırmalarda da azotun bölünerek verilmesi hektolitre ağırlığı üzerine olumlu etki yapmıştır [13]; [15].

\subsection{Camsılık özelliği}

Farklı azot dozlarında ve farklı sıvı gübre uygulamalarının Kızıltan -91 buğday çeşidinin camsılık özelliği üzerine etkisi istatistiki olarak önemsiz bulunmuștur (Tablo 10). Uygulamalara göre ortalama camsılık değerleri 93.00-94.67 arasında değişmiştir. Azot dozu yüksek olduğunda camsılık değeri azalmış ancak bu farklılık önemli bulunmamıştır. Yine 1 ve 6 numaralı uygulamalarda camsıllk değeri daha yüksek bulunmuştur. Genel olarak tanedeki camsı yapı ile protein miktarı arasında bir ilişki (olumlu veya olumsuz?) bulunmaktadır. Ancak bu araştırmada protein oranı üzerine uygulamaların etkisi önemli iken, camsılık üzerine uygulamaların etkisi önemsiz bulunmuştur. Camsı tane oranı çeşide, iklim ve toprak koşullarına göre değişiklik gösterebilmektedir.

\subsection{Protein oranı (\%)}

Kızıltan-91 buğday çeşidinin protein oranı üzerine, farklı azot dozlarının ve uygulamaların etkisi önemli ( $\mathrm{p}<0.01)$ bulunmuştur. Tablo 11' de görüldüğü gibi, Kızıltan -91 buğday çeşidinde ortalama protein oranı $8 \mathrm{~kg} / \mathrm{da}$ azot dozunda \%14.54 iken, $14 \mathrm{~kg} / \mathrm{da}$ azot uygulamasında \%15.32 olarak elde edilmiştir. Bu çalışmada en yüksek protein oranı, $14 \mathrm{~kg} / \mathrm{da}$ azot 5 numaralı uygulamada $(1 / 2$ ekim $+1 / 2$ erken ilkbahar +Süper tonik) elde edilmiştir. Azotun üçe bölünerek verilmesi sonucunda protein oranının azaldığı bulunmuştur. Genel olarak azot gübresine ilave olarak sıvı gübre kullanımının protein oranını ve verimini artırdığı sonucuna varılmıștır Farklı araştırmalarda değişik içeriklere sahip yaprak gübrelerinin buğdayda tanedeki protein içeriğini artırdığı ileri sürülmüştür $\quad[18 ; 19 ; 20]$.

Tablo 10. Farklı azot dozu ve sıvı gübre kullanımlarının camsılık özelliğine olan etkisi

\begin{tabular}{|c|c|c|c|c|}
\hline \multirow[b]{2}{*}{ No } & \multirow[b]{2}{*}{ Azot ve Sivı Gübre Uygulamaları } & \multicolumn{2}{|c|}{ Azot Dozları (kg/da) } & \multirow[b]{2}{*}{ Ortalama } \\
\hline & & 8 & 14 & \\
\hline 1 & 1/2 ekim+1/2 sapa kalkma başlangıcl & 95.33 & 94.00 & 94.67 \\
\hline 2 & $1 / 3$ ekim $+1 / 3$ erken ilkbahar $+1 / 3$ sapa kalkma & 94.00 & 92.67 & 93.33 \\
\hline 3 & $1 / 2$ ekim $+1 / 2$ erken ilkbahar + amino turbo & 94.00 & 92.00 & 93.00 \\
\hline 4 & $1 / 2$ ekim $+1 / 2$ erken ilkbahar + biomax & 94.67 & 94.00 & 94.33 \\
\hline 5 & $1 / 2$ ekim+1/2erken ilkbahar +süper tonik & 93.33 & 94.00 & 93.67 \\
\hline \multirow[t]{2}{*}{6} & $1 / 2$ ekim $+1 / 2$ erken ilkbahar + folvinex & 95.33 & 94.00 & 94.67 \\
\hline & Ortalama & 94.44 & 93.44 & \\
\hline
\end{tabular}

F değerleri : Azot Dozu (A) : 1.286 ns ; Uygulama(B) : 0.721 ns, A X B : 0.300

$\mathrm{CV}(\mathrm{a})=\% 2,82, \mathrm{CV}(\mathrm{b})=\% 2,19$

ns: önemli değil

Tablo 11. Farklı azot dozu ve sıvı gübre kullanımlarının protein oranı (\%) olan etkisi

\begin{tabular}{|c|c|c|c|c|}
\hline \multirow[b]{2}{*}{ No } & \multirow[b]{2}{*}{ Azot ve Sıvı Gübre Uygulamaları } & \multicolumn{2}{|c|}{ Azot Dozları (kg/da) } & \multirow[b]{2}{*}{ Ortalama } \\
\hline & & 8 & 14 & \\
\hline 1 & 1/2 ekim+1/2 sapa kalkma bașlangıcı & 14.45 & 15.17 & $14.81 \mathrm{ab}^{*}$ \\
\hline 2 & $1 / 3$ ekim $+1 / 3$ erken ilkbahar $+1 / 3$ sapa kalkma & 13.56 & 14.44 & $14.00 \mathrm{~b}$ \\
\hline 3 & $1 / 2$ ekim $+1 / 2$ erken ilkbahar + amino turbo & 14.33 & 14.85 & $14.59 \mathrm{ab}$ \\
\hline 4 & $1 / 2$ ekim $+1 / 2$ erken ilkbahar + biomax & 14.91 & 15.55 & 15.23ab \\
\hline 5 & 1/2 ekim+1/2erken ilkbahar +süper tonik & 15.15 & 16.00 & $15.58 \mathrm{a}$ \\
\hline 6 & $1 / 2$ ekim $+1 / 2$ erken ilkbahar + folvinex & 14.81 & 15.90 & $15.36 \mathrm{a}$ \\
\hline & Ortalama & $\begin{array}{l}14.54 \\
\mathrm{~B}\end{array}$ & $15.32 \mathrm{~A}$ & \\
\hline
\end{tabular}

F değerleri : Azot Dozu (A) : $109.743^{* *}$; Uygulama(B) : $7.338^{* * ;}$ A X B : 0.218

$\mathrm{CV}(\mathrm{a})=\% 1,5, \mathrm{CV}(\mathrm{b})=\% 3,52$

*Aynı harfle gösterilen değerler arasında istatistiksel olarak fark yoktur. ${ }^{* *}: \mathrm{P} \leq 0.01$ düzeyinde önemli 


\section{Sonuç}

Sonuç olarak, Uşak yöresinde gübre dozu azaltılarak, sıvı gübre ilavesi ile verimin yeterli seviyeye ulaștırılması mümkün değildir. Ayrıca atılacak sıvı gübrelerin içeriğinin önemli olduğu her sıvı gübrenin verim ve kalite üzerine etkisi olmadığı belirlenmiştir. $\mathrm{Bu}$ araştırmada seçilen ve piyasada Folvinex adı ile satılan sıvı gübrenin Kızıltan-91 çeşidinde verim ve kalite özelliği üzerine etkili olduğu belirlenmiştir. Ancak uygulamaların etkinliğinin çevresel faktörlerden etkilendiği düşünülürse, kesin yargılara ulaşabilmek için denemenin en az bir yll daha yürütülmesi gerektiği söylenebilir.

\section{Teşekkür}

$\mathrm{Bu}$ araștırma, Yüksek Lisans Tezinden hazırlanmıștır ve SDÜ-BAP birimi tarafından 3596-YL1-13 nolu proje olarak desteklenmiştir. Desteklerinden dolayı Süleyman Demirel Üniversitesi BAP birimine teşekkür ederiz.

\section{Kaynakça}

[1] Shewry, P. R., 2009. Wheat. J. Experimental Botany, 60( 6): 1537-1553.

[2] Anonim, 2015. Türkiye İstatistik Kurumu http://www.tuik.gov.tr.

[3] Çölkesen, M., Eren, N., Aslan, S., Öktem, A., 1993. Şanlıurfa'da Sulu ve Kuru Koşullarda Farklı Dozlarda Uygulanan Azotun Diyarbakır-81 Makarnalık Buğday çeşidinde Verim ve Verim Unsurlarına Etkisi Üzerine Bir Araștırma. Makarnalık Buğday Mamülleri Sempozyumu, 486495 (30 Kasım-3 Aralık), Ankara.

[4] Frederick, J. R., Camberato, J. J., 1995. Water and Nitrogen Effectes on Winter Wheat in the Southeastern Coastal Plain: I. Grain Yield and Kernel Traits. Agron. J., 87(3): 521-526.

[5] Genç, İ. Ülger, A.C., Yağbasanlar, T., Kırtok, Y., Topal, M., 1988. Çukurova Koşullarında Tritikale, Buğday ve Arpanın Verim ve Verim Öğeleri Üzerinde Kıyaslamalı Bir Araştırma. Çukurova Üniv. Ziraat Fak. Degisi, 3(2): 1- 14.

[6] Sağlam, N., 1992. Trakya Koșullarında Beş Makarnalık Buğday Çeşidinde Farklı Azotlu Gübre Dozları ve Verilme Zamanlarının Verim ve Kalite Üzerine Etkileri. Trakya Üniversitesi, Fen Bilimleri Enstitüsü, 178 s, Doktora Tezi. Tekirdağ.

[7] Dere, Ş., 1995. Samsun Ekolojik Şartlarında Farklı Zamanlarda Uygulanan Azotlu Gübre ve Yabancı Ot İlaçlarının Ekmeklik Buğdaylarda Verim,Verim Unsurları ve Bazı Kalite Kriterlerine Etkileri. Ondokuz Mayıs Üniversitesi, Fen Bilimleri Enstitüsü, Yüksek Lisans Tezi, 61 s, Samsun.

[8] Coşkun, Y., 2003. Farklı Dozlarda ve Zamanlarda Uygulanan Azotun Makarnalık Buğdayın Verim ve Verim Unsurları Üzerine Etkileri. Harran Üniversitesi, Fen Bilimleri Enstitüsü, Yüksek Lisans Tezi, 74 s, Şanlıurfa.
[9] Darwinkel, A., 1983. Ear Formation and Grain Yield of Winter Fertilization. Wheat as Affected by Time of Nitrogen Supply. Neth. J. Agric.Sci. 31, 211-225.

[10] Ewert F., Honermeier, B. 1999. Spikelet initiation of winter triticale and winter wheat in response to nitrogen fertilization. European Journal of Agronomy ,11: 107-113.

[11] Alcoz, M. M., Hons, M. Frank, Haby, Vincent A., 1993. Nitrogen Fertilization Timing Effect on Wheat Production, Nitrogen Uptake Efficiency, and Residual Soil Nitrogen Agron J. 85: 11981203.

[12] Evlice, K.A., Kara R., Sezal, M,. Dokuyucu, T., Akkaya, A., 2008. Kahramanmaras Kosullarında Azot Uygulama Zamanlarının Ekmeklik Buğdayda (Triticum aestivum L.) Fenolojik Donemler, Verim ve Verim Unsurlarına Etkisi. Tarla Bitkileri Merkez Araştırma Enst. Derg. 17 (1-2):1-11.

[13] Ottman, M. J., Thomas, A. D., Edward, C. M., 2000. Durum Grain Quality as Affected by Nitrogen Fertilization Near Anthesis and Irrigation During Grain Fill. Soil Sci. Soc. Am. J. 92:1035-1041.

[14] Biçer, M., 2001. Bazı Makarnalık Buğday Çeşitlerinde Farklı Gelişme Dönemlerinde Verilen Azotlu Gübrelerin Verim ve Kalite Öğelerine Etkisi. Ankara Üniversitesi, Fen Bilimleri Enstitüsü, Yüksek Lisans Tezi, 52 s, Ankara.

[15] Kahraman, T., 2006. Bazı Ekmeklik Buğday Çeşitlerinde Farklı Ekim Zamanı ve Azotlu Gübre Uygulamalarının, Tane Dolum Süresi ve Tane Dolum Oranı ile Verim ve Kalite Unsurlarına Etkilerinin Belirlenmesi. Trakya Üniversitesi, Fen Bilimleri Enstitüsü, Doktora Tezi, 160 s, Tekirdağ.

[16] Avcl, R., 2007. Farklı Azotlu Gübre Uygulamalarının Ekmeklik Buğdayda Verim ve Kalite Üzerine Etkileri. Trakya Üniversitesi, Fen Bilimleri Enstitüsü, Yüksek Lisans Tezi, 81 s, Tekirdağ.

[17] Christensen, N. W. and Meints, V. W., 1982. Evaluating $\mathrm{N}$ Fertilizer Sources and Timing for Winter Wheat. Agron. J., 74: 840-844.

[18] Nazar, H. 2012. Ekmeklik Buğdayda (Triticum aestivum L.) Farklı Besin Maddesi İçerikteki Yaprak Gübrelerinin Verim, Verim Öğeleri ve Kalite Özelliklerine Etkisinin Belirlenmesi. Adnan Menderes Üniversitesi, Fen Bilimleri Enstitüsü, Yüksek Lisans Tezi, 53 s, Aydın.

[19] İpek, M., 2013. Buğdayda (Triticum aestivum L.) Çinko ve Fosfor Uygulamalarının Verim ve Verim Öğelerine Etkisi. Yüzüncü Yıl Üniversitesi, Fen Bilimleri Enstitüsü, Yüksek Lisans Tezi, 69 s, Van.

[20] Baysal, Z., 2014. Aydın Ekolojik Koşullarında Çinko Uygulamasının Buğday'ın (Triticum aestivum L.) Tane Verimi ve Kalitesi Üzerine Etkisi. Adnan Menderes Üniversitesi, Fen Bilimleri Enstitüsü, Yüksek Lisans Tezi, 59 s, Aydin. 